NBER WORKING PAPER SERIES

\title{
HOW WELL DO PARENTS WITH YOUNG CHILDREN COMBINE WORK AND FAMILY LIFE?
}

\author{
Christopher J. Ruhm \\ Working Paper 10247 \\ http://www.nber.org/papers/w10247 \\ NATIONAL BUREAU OF ECONOMIC RESEARCH \\ 1050 Massachusetts Avenue \\ Cambridge, MA 02138 \\ January 2004
}

\begin{abstract}
Research assistance from Stuart Spencer and financial support from the National Institute of Child Health and Human Development (HD38521-01A1), the National Science Foundation (SES-9876511), and the Russell Sage Foundation Program on the Social Dimensions of Inequality is gratefully acknowledged. All opinions, findings, conclusions, and recommendations are those of the author and do not necessarily reflect the views of the funding agencies. "How Well Do Parents With Young Children Combine Work and Family Life", in Suzanne M. Bianchi, Lynne M. Casper, Kathleen E. Christensen, and Rosalind Berkowitz King (eds.) Work, Family, Health and Wellbeing, Lawrence Erlbaum Associates, forthcoming. The views expressed herein are those of the authors and not necessarily those of the National Bureau of Economic Research.
\end{abstract}

(C)2004 by Christopher J. Ruhm. All rights reserved. Short sections of text, not to exceed two paragraphs, may be quoted without explicit permission provided that full credit, including (C) notice, is given to the source. 
How Well Do Parents With Young Children Combine Work and Family Life?

Christopher J. Ruhm

NBER Working Paper No. 10247

January 2004

JEL No. I0, J2

ABSTRACT

This study examines trends in labor force involvement, household structure, and some activities that may complicate the efforts of parents with young children to balance work and family life. Next I consider whether employer policies mitigate or exacerbate these difficulties and, since the policies adopted in the United States diverge dramatically from those in many other industrialized countries, provide some international comparisons before speculating on possible sources and effects of the differences.

Christopher J. Ruhm

Department of Economics

University of North Carolina at Greensboro

P.O. Box 26165

Greensboro, NC 27402-6165

and NBER

c-ruhm@uncg.edu 


\section{How Well Do Parents With Young Children Combine Work and Family Life?}

The first years of life are a particularly important period for children (Carnegie Task Force on Meeting the Needs of Young Children, 1994; Council of Economic Advisers, 1997). Recent research emphasizes the effects of early influences on brain development (Shore, 1997) and investments during young childhood are likely to be significant for the growth of learning skills, self-esteem and emotional security (Heckman, 2000). ${ }^{1}$ Many parents face particular demands in the workplace during these same years as they attempt to establish or advance careers and meet the financial needs of their growing families. These pressures may be aggravated by job insecurity, increases in the pace of work, and other burdens such as the need to care for aging relatives.

This study examines trends in labor force involvement, household structure, and some parental activities that may complicate efforts to balance work and family life. Next I consider whether employer policies mitigate or exacerbate these difficulties and, since the policies adopted in the United States diverge dramatically from those in many other industrialized countries, provide some international comparisons before speculating on possible sources and effects of the differences.

\section{Changes in Labor Supply, Household Composition, and Time Investments}

The rapidly increasing involvement of women in the workplace in recent decades represents a well-known but nevertheless striking change. The labor force participation rate (LFPR) of females aged 16 and over rose from 43.3 to 60.1 percent between 1970 and 2001; conversely participation of males declined slightly during the same period (mainly due to earlier retirement), falling from 79.7 to 74.4 percent (U.S. Bureau of the Census, 2002).

The overall rise in female participation masks still larger increases among mothers. As shown in Figure 1, the LFPR of mothers with non-adult children rose 54 percent between 1975 and 2001, from 47.4 to 73.1 percent (U.S. Department of Labor, Bureau of Labor Statistics, 1988; U.S. Bureau of the Census, 2002). The implication that most children now have working

\footnotetext{
${ }^{1}$ However, the mechanisms for these effects are poorly understood and the relationship between early brain development and future outcomes remains controversial (Bruer, 1999).
} 
mothers suggests that tradeoffs between work and family responsibilities may have become more difficult for many households. The issue is even more salient for parents with young children. Labor force participation rates for women with children under 6 years of age grew 66 percent over the same time span (from 39.0 to 64.9 percent), while the LFPR of mothers with infants increased 78 percent, from 31.0 to 55.2 percent, between 1976 and 2000 (Bachu and O'Connell, 2001).

Women with young children are also much less likely to have a spouse available to help with household responsibilities. In 1960, just 8 percent of children lived only with their mother and fully 88 percent were in two-parent households; the corresponding figures in 2002 were 23 and 69 percent (U.S. Bureau of the Census, 2003). ${ }^{2}$ Single-parent households are likely to have a far more difficult time balancing the conflicting demands of work and family.

Government policies may have exacerbated these challenges. Employment used to be uncommon for married mothers with young children but has become the norm. (Single mothers have always had higher rates of participation.) As shown in Figure 2, the LFPR of married mothers with children under 6 grew 70 percent (from 36.7 to 62.5 percent), compared to a 40 percent increase (from 51.3 to 72.0 percent) for corresponding single mothers. ${ }^{3}$ Even more striking is that the participation of single mothers remained essentially constant between 1975 and 1992 and then began to rise very rapidly. A comprehensive analysis by Meyer and Rosenbaum (2001) indicates that this increase can largely be attributed to changes in the Earned Income Tax Credit (EITC) and other tax policies, as well as welfare reform. ${ }^{4}$

Increases in the market employment by mothers and children in single-parent households suggest that families may find it increasingly difficult to balance conflicts between responsibilities at home and in the workplace. However, there are two mitigating factors. First, women are not having as many children as they used to - the total fertility rate fell from 3.65 to

\footnotetext{
${ }^{2}$ The percentage of children living only with fathers also rose (from 1.1 to 4.6 percent) between 1960 and 2002, while the share living with non-parent relatives changed little (from 2.5 to 2.9 percent).

${ }^{3}$ Married couples are defined here to include cases where the spouse is living in the household; single parents refer to adults who are divorced, separated, widowed, or have never married.

${ }^{4}$ Conversely, Eissa and Hoynes (1998) estimate that the EITC slightly reduced (by about one percentage point) the employment rates of married women.
} 
2.08 children between 1960 and 1999 (U.S. Bureau of the Census, 2001, Table 1-7) - implying ceteris paribus that more time is available for each child. Second, mothers have significantly decreased the time spent on housework, in part because of increased contributions by fathers: between 1965 and 2000 mothers reduced housework from 32 to 19 hours per week while the time spent by fathers rose from 4 to 10 hours weekly (Bianchi and Raley, 2003).

The decrease in housework represents one of a variety of efforts by mothers to protect their investments in children. ${ }^{5}$ Nevertheless, evidence from time-diaries confirms that working mothers spend less time with children than nonemployed women (Bryan and Zick, 1996; Zick and Bryan, 1996; Bianchi, 2000; Gershuny, 2000; Hofferth, 2001; Sandberg and Hofferth, 2001). And long work hours are likely to have other costs. For instance, parents may be more tired or stressed, and they are likely to cut back on valued activities such as sleep, leisure pursuits, and personal care (Bianchi, 2000). ${ }^{6}$

\section{Employer Benefits}

Are private employers in the United States "family-friendly"? While there are many dimensions to this question, one obvious aspect to consider are the types of benefits offered by companies. Towards this end, Tables 1 and 2 document the availability of employer-provided benefits to full-time workers that might help with balancing responsibilities at home and in the workplace. Table 1 provides information on medium and large establishments; Table 2 offers corresponding data for small employers. ${ }^{7}$

Over 90 percent of full-time employees at medium and large companies receive (often brief) paid holidays and vacation. However, even these have become somewhat more limited over time: the share of full-time workers supplied with holidays and vacations has drifted down from 96 and 98 percent in 1988 to 92 and 95 percent in 2000. The majority of full-time

\footnotetext{
${ }^{5}$ Increased involvement by fathers may be another response, as are efforts to synchronize work schedules.

${ }^{6}$ For example, working mothers sleep 6 hours $(10$ percent) less per week than their nonemployed counterparts. The Council of Economic Advisers (1999) estimated that parents had 22 hours (14 percent) less time available for children in 1969 than in 1999; however, Sandberg and Hofferth (2001) find that, since the early 1980s, parents have changed their behavior so as to avoid reducing the time devoted to children.

${ }^{7}$ Medium and large establishments are defined as those employing more than 100 workers after 1986. In earlier years, the size threshold was set between 50 and 250 workers, depending on the industry.
} 
employees can also take paid sick leave, although there is again some suggestion of a downward trend. Other paid benefits are rare. Between 20 and 25 percent receive paid personal leave; less than one-tenth obtain employer assistance for child care; and fewer than one in twenty works for an employer offering either on-site or off-site child care. By contrast, unpaid family leave is more common - it was available to one-third of women and one-sixth of men working full-time for medium or large employers in 1988 and was almost universally offered to them by the late 1990s. This change reflects the enactment of federal legislation that is discussed below.

Although corresponding information for small employers has been available for a shorter period, there is no doubt that such companies supply family-friendly benefits less often than their larger counterparts. ${ }^{8}$ Fewer than 90 percent of full-time employees at small firms received paid holidays or vacations and sick leave was provided to roughly half of them. Paid personal leave was available to just one in eight full-time employees in the early and mid-1990s and paid family leave or child care was almost never provided. Unpaid family leave increased sharply over time, just as for larger companies, but was still offered to less than half of full-time employees in 1996.

Firms are even less likely to offer the aforementioned benefits to part-time and lessskilled workers, who will often have the fewest resources available to mitigate work-family conflicts. For instance, 90 and 87 percent of full-time employees of private firms (of all sizes) received paid vacations and holidays in 1999, compared to 43 and 36 percent of part-time workers (U.S. Department of Labor, Bureau of Labor Statistics, 2001). Similarly, 88, 89, and 12 percent of managerial, technical, and professional employees were offered paid vacations, paid holidays, and child care assistance versus 75, 69, and 4 percent of blue-collar or service employees.

\section{Family Leave Policies}

As noted, one benefit that has expanded markedly in recent years is in the availability of unpaid family leave. Where just one-third of females and one-sixth of males employed full-time at medium or large establishments were able to take unpaid family leave in 1990, over 90 percent

\footnotetext{
${ }^{8}$ However, small employers might be more likely to make accommodations to employees on an informal basis.
} 
of both sexes could do so in 1997. This largely resulted from the 1993 enactment of the federal Family and Medical Leave Act (FMLA).

Key provisions of the FMLA are detailed in Table 3. Briefly, the law requires public agencies and sufficiently large private establishments to offer 12 weeks of leave during a oneyear period to employees caring for newborn or adopted children, relatives with serious medical conditions, or for their own health problems. The entitlement is limited in several ways. Most importantly, the leave is unpaid and workers may be required to first use accrued sick leave or vacation time. However health insurance is continued. Small employers (those with fewer than 50 employees in a 75-mile radius) are exempt and, under specified conditions, firms are not required to offer job reinstatement (at the end of the leave) to certain "key" employees.

The exemption of small firms, exclusion of key employees, and work history requirements limit the scope of FMLA coverage. In earlier work (Ruhm, 1997), I estimated that approximately half of all workers are covered by the law. Also, while this legislation is often viewed as providing parental leave to care for newborns, the FMLA is primarily used for other purposes. For instance, in 1995 just 14.3 percent of employees taking FMLA leave did so to care for a newborn or newly adopted child; in 2000, 17.9 percent of leaves were for this purpose (Waldfogel, 2001). ${ }^{9}$ One reason for this is that many women eligible for maternity leave under the FMLA already had the rights to job absences under the Pregnancy Discrimination Act (PDA) of 1978, temporary disability insurance programs in some states (that extend beyond the PDA), and state leave laws covering private and public employees. ${ }^{10}$

The situation in the United States contrasts sharply with that in most other nations. In 1999 more than 125 countries, including virtually all industrialized nations, provided some form of paid job-protected maternity leave, most entitling women to at least two or three months of paid leave during the period surrounding childbirth (Kamerman, 2000). To illustrate, Table 4 details the paid leave entitlements, rate of pay, source of funds, and conditions for eligibility in 2002 for 15 European nations. Each provides at least 12 weeks of leave, usually at between 50

\footnotetext{
${ }^{9}$ By far the most common reason for taking leave is for one's own health problem - accounting for 61.4 percent of FMLA absences in 1995 and 47.2 percent in 2000.

${ }^{10}$ Ruhm (1997) provides a more detailed discussion of this issue.
} 
and 100 percent of pay, and many provide rights to much longer job absences. Moreover, the leave durations are often extended in cases of complicated pregnancy or child birth, sick children, or for other reasons (such as multiple births). A portion of the leave is sometimes available to fathers and additional lengthy unpaid job absences with guaranteed reemployment are frequently permitted after the end of the paid leave period.

\section{Maternal Employment and Child Care}

Due in part to the limited availability of paid parental leave, most women in the United States quickly return to work after giving birth. Figures 3 details employment rates following pregnancy for mothers having babies during the early 1980s through mid-1990s. ${ }^{11}$ One-fourth were absent from jobs less than one week after delivery, although a small fraction of these may have initially been on brief maternity leaves. The "conditional" estimates show employment rates for women taking some time off work after birth; the "unconditional" probabilities refer to all mothers. Weekly employment hazard rates (displayed in percentages and multiplied by 10) averaged 4 to 8 percent for the first 10 weeks of the child's life, declined rapidly to 1 to 2 percent in the fourth through sixth months, and were less than 1 percent during the remainder of the first year. $^{12}$ The hazard rates typically ranged between 0.2 and 0.6 percent per week in the child's second year and 0.1 to 0.2 percent in the third. Sixty-five, 77 , and 84 percent of women returned to jobs prior to their child's first, second, and third birthday, as did 53, 70, and 79 percent of those taking some time off work after delivery.

Since most mothers work in their children's early years, the majority of families use nonparental day care. The cost of this care sometimes presents difficulties and necessitates a variety of adjustments. In recent research, Dan Rosenbaum and I have attempted to measure the "cost burden" of child care (Rosenbaum and Ruhm, 2003), defined as day care expenses for children aged five and under divided by disposable income (earnings plus non-earned income minus taxes). Table 5 summarizes some of our estimates. The average pre-school aged child lives in a family spending 4.9 percent of their disposable income on day care. This average, however,

\footnotetext{
${ }^{11}$ These data are from the 1979 cohort of the National Longitudinal Survey of Youth. Ruhm (forthcoming) provides additional detail on the sample and results.

${ }^{12}$ The hazard rate is the probability of working in a given week conditional on the mother not being employed the previous week.
} 
conceals enormous diversity. Fully 63 percent of children live in families with no child care costs. Conversely, families in the upper 10 percent of the cost burden distribution spend nearly 30 percent of disposable income on child care. ${ }^{13}$

The concentration of child care costs is remarkable. Families in the top decile of the cost burden distribution average $\$ 624$ per month for child care, versus only $\$ 80$ per month for the other 90 percent of families, yet have monthly disposable incomes averaging just $\$ 2,268$, which is less than the $\$ 3,150$ mean monthly income of the other 90 percent. One reason is that working single parents account for 40 percent of the highest cost burden group. However, zero costs need not imply an absence of nonparental day care as 23 percent of young children are in families that utilize only free sources of care. These households are disproportionately disadvantaged, as measured by the predicted earnings of the primary caregiver based on characteristics such as education, age of the parent, and race/ethnicity.

Table 6 provides further information on the sources and costs of day care. Children under 6 reside in families where an average of 25 hours per week of care is provided by persons other than parents or siblings. Sixty percent are in families using some external sources of day care, two-fifths of which is provided free of charge (mostly by grandparents and other relatives). The quantity and cost of care varies substantially across types of families. Rosenbaum and Ruhm (2003) estimate that single-parent families use 50 percent more hours than married parents (33 vs. 22 hours per week) but also utilize cheaper sources ( $\$ 0.80$ vs. $\$ 1.50$ per hour on average) and as a result spend 20 percent less on child care ( $\$ 114$ vs. $\$ 143$ per week). Families where the primary caregiver is a non-Hispanic white use slightly fewer hours of outside day care than minorities (24 vs. 27 hours per week) but pay more per hour (\$1.49 vs. \$0.87) and per month (\$155 vs. \$100) for these services. Highly educated parents use large amounts and expensive sources of day care, resulting in relatively high expenditures.

\section{Implications}

Balancing employer and family responsibilities presents particular challenges to parents with young children in the United States, probably more so than in many other industrialized

${ }^{13}$ The $75^{\text {th }}, 90^{\text {th }}$, and $95^{\text {th }}$ percentiles of the cost burden distribution are 5.9, 16.3 , and 25.3 percent. 
countries. The U.S. labor market can reasonably be characterized as one with long work hours, short vacations, limited availability of parental leave, and restricted state or employer support for child care. ${ }^{14}$ Grandparents and other relatives often help supervise young children, raising the possibility that workplace-family concerns span generations.

That said, considerable caution is needed before assuming that the more "familyfriendly" institutional arrangements present in other nations would be desirable for the United States. There is good reason to believe that many Americans willingly tradeoff higher labor supply and reduced workplace flexibility for increased incomes. The U.S. is also characterized by a particularly high reliance on market-based solutions and distrust of government regulations or interventions. In the absence of significant sources of market failure, public goods, or externalities, privately negotiated labor market arrangements lead to economically efficient (although not necessarily equitable) solutions and regulations impose net costs on society. Thus, one interpretation of the findings is that employers provide and the government mandates few family-friendly benefits because the public prefers it that way.

These points notwithstanding, my suspicion is that the work-family arrangements common in the United States are suboptimal. There is increasing evidence that paid parental leave that is not too lengthy improves the labor market outcomes of women (Ruhm, 1998; Baum, 2003a), enhances child health (Ruhm, 2000), and raises the quality of mother-infant interactions (Clark et al., 1997). Recent research on maternal employment, that contains better controls and more sophisticated strategies for accounting for heterogeneity than earlier studies, finds that labor supply during the child's infancy period has a deleterious impact on cognitive development (e.g. Han et al., 2001; Brooks-Gunn et al., 2002; Baum, 2003b; Ruhm, 2003; Ruhm, 2004). There is also evidence that high quality formal day care in the year prior to kindergarten increases school readiness (Shonkoff \& Phillips, 2001; Magnuson, et al., forthcoming). Taken as a group, these results seem at odds with limited rights to parental leave, elevated levels of market

\footnotetext{
${ }^{14}$ Altonji and Oldham (2003) provide evidence linking long annual work hours in the United States to the absence of legislation mandating minimum paid time off work, in sharp contrast to all Western European countries (other than the United Kingdom) where employees are generally entitled to lengthy vacations.
} 
employment by parents with young children, and the high cost of (frequently poor quality) formal child care arrangements.

Moreover, there are several reasons why voluntarily negotiated private arrangements may fail to yield efficient or desirable solutions. Adverse selection under asymmetric information provides a potential source of market failure. For example, companies voluntarily offering extensive paid parental leave may attract a disproportionate number of employees likely to use the costly benefit. If these expenses are financed by lower earnings, persons with small probabilities of using leave will avoid such firms and so do without even socially optimal job absences. ${ }^{15}$ Conversely, if the employers are unable to sufficiently reduce wages to offset costs of the leave, profits will fall and economic viability may be threatened. A government mandate eliminates the incentive for this type of sorting behavior and has the potential to raise welfare.

Privately negotiated arrangements might also fail to provide first-best outcomes if parents lack information on the results of their decisions. For instance, they may not be sufficiently informed about the quality of alternative child care options or the consequences of different choices. Similarly, if parents are liquidity constrained and capital markets are imperfect, they may be unable to finance desired expenditures on high quality but costly day care. Another reason families might underinvest in children is if some of the benefits represent "public goods". For instance, high quality child care could increase school readiness which, in turn, subsequently leads to lower the crime rates during adolescence. Certain types of medical care may similarly reduce health risks to other children (e.g. by decreasing communicable diseases). However, many of these benefits will not be directly observed by the parents (or employers) paying the additional costs, reducing incentives to undertake the expenditures. That said, it is often not obvious how (if at all) these sources of market failure can best be remedied.

\footnotetext{
${ }^{15}$ This is analogous to Rothschild and Stiglitz's [1976] argument for market failure in insurance markets. Aghion and Hermalin [1990] suggest that in some situations socially optimal parental leave might not be voluntarily provided to any workers. This might occur because low-risk individuals signal their status to employers by agreeing to contracts providing for little or no leave. High-risk workers sometimes do better mimicking their counterparts, by taking positions without leave, than by revealing their propensity towards absenteeism. The inefficiency of privately negotiated labor contracts under asymmetric information has been demonstrated across a variety of contexts.
} 
Government policies that have desirable aims may nevertheless make it more difficult for parents with young children to balance their joint work-family responsibilities. Most obviously, reforms to the welfare system have placed pressure on recipients (particularly single mothers) to quickly enter or resume employment, possibly increasing time constraints and the difficulties in caring for children. More generous tax treatment under the Earned Income Tax Credit has similarly raised the labor supply of single mothers with young children. The higher levels of employment represent voluntary (and presumably largely desirable) responses to increases in the returns to work but may nevertheless place stresses on some families. The proposed elimination of the "marriage penalty" could also create incentives for married individuals (especially mothers) with young children to increase employment hours, again highlighting issues of workfamily balance.

The aforementioned government policies all operate to raise employment, earnings, and presumably national income. However, they have generally not been accompanied by aggressive efforts to facilitate combining increasing job responsibilities with the needs of families. As discussed, paid parental leave is a rarity in the United States, child care options are limited, and vacations are short. Changing these or related family-friendly policies through government programs, regulations, or direct employer actions is likely to be expensive and controversial. Discussion of what courses of action might best assist families with young children is worthy of future debate. 


\section{References}

Aghion, Philippe and Benjamin Hermalin. 1990. "Legal Restrictions on Private Contracts Can Enhance Efficiency” Journal of Law, Economics, and Organization, 6(2), fall, 381-409.

Altonji, Joseph G. and Jennifer Oldham. 2003. "Vacation Laws and Work Hours", Federal Reserve Bank of Chicago: Economic Perspectives, 27(3), $3{ }^{\text {rd }}$ Quarter, 19-29.

Bachu, Amara and Martin O'Connell. 2000. Fertility of American Women: June 1998, U.S. Census Bureau, Current Population Report P250-526, September.

Bachu, Amara and Martin O'Connell. 2001. Fertility of American Women: June 2000. U.S. Census Bureau, Current Population Reports, P20-543RV. Historical tables: Table H5. Accessed June 10, 2003 from: http://landview.census.gov/population/socdemo/fertility/tabH5.pdf

Baum, Charles L. 2003. "The Effects of Maternity Leave Legislation on Mothers' Labor Supply After Childbirth”, Southern Economic Journal, 69(4), April, 772-799. (2003a)

Baum, Charles L. 2003. "Does Early Maternal Employment Harm Child Development? An Analysis of the Benefits of Leave Taking", Journal of Labor Economics, 21(2), April, 409448. (2003b)

Bianchi, Suzanne. 2000. "Maternal Employment and Time With Children: Dramatic Change or Surprising Continuity" Demography, 37(4), 401-414.

Bianchi, Suzanne M. and Sara Raley. 2003. "Changing Work and Family Demographics” this volume.

Brooks-Gunn, Jeanne, Wen-Jui Han, and Jane Waldfogel. 2002. "Maternal Employment and Child Cognitive Outcomes in the First Three Years of Life: The NICHD Study of Early Child Care", Child Development 73(4), 1052-1072.

Bruer, John T. 1999. The Myth of the First Three Years: A New Understanding of Early Brain Development and Lifelong Learning. New York: The Free Press.

Bryant, W. Keith and Cathleen D. Zick. 1996. "An Examination of Parent-Child Shared Time", Journal of Marriage and the Family 58(1), 227-237.

Carnegie Task Force on Meeting the Needs of Young Children. 1994. Starting Points: Meeting the Needs of Our Youngest Children. New York: Carnegie Corporation of New York.

Clark, Roseanne, Janet Shibley Hyde, Marilyn J. Essex, and Marjorie H. Klein. 1997. "Length of Maternity Leave and Quality of Mother-Infant Interactions”, Child Development, 68(2), November, 364-383.

Council of Economic Advisers. 1999. Families and the Labor Market, 1969-1999: Analyzing the "Time Crunch". Washington, DC: Council of Economic Advisers, Executive Office of the President, May. 
Council of Economic Advisers. 1997. The First Three Years: Investments that Pay. Washington, DC: Council of Economic Advisers, Executive Office of the President, April 17.

Eissa, Nada and Hilary Williamson Hoynes. 1998. "The Earned Income Tax Credit and the Labor Supply of Married Couples", National Bureau of Economic Research Working Paper No. 6856, December.

Gershuny, Jonathan. 2000. Changing Times: Work and Leisure in Postindustrial Society. New York: Oxford University Press.

Han, Wen-Jui, Jane Waldfogel, and Jeanne Brooks-Gunn. 2001. "The Effects of Early Maternal Employment on Later Cognitive and Behavioral Outcomes", Journal of Family and Marriage, 63, February, 336-354.

Heckman, James J. 2000. "Policies to Foster Human Capital” Research In Economics, 54(1), March, 3-56.

Hofferth, Sandra L. 2001. "Women's Employment and Care of Children in the United States", in Tanja van der Lippe and Liset van Dijk (eds.), Women's Employment In A Comparative Perspective. New York: Aldine de Gruyter, 151-174.

Kamerman, Sheila B. 2000. "Parental Leave Policies: An Essential Ingredient in Early Childhood Education and Care Policies" Social Policy Report, 14(2), 3-15.

Magnuson, Katherine A., Marcia Meyers, Christopher J. Ruhm, and Jane Waldfogel. Forthcoming. "Inequality in Pre-School Education and School Readiness", American Education Research Journal.

Meyer, Bruce D. and Dan T. Rosenbaum. 2001. "Welfare, the Earned Income Tax Credit, and the Labor Supply of Single Mothers", Quarterly Journal of Economic Research 116(3), August, 1063-1113.

Rosenbaum, Dan T. and Christopher J. Ruhm. 2003. "Caring for Young Children: Inequality in the Cost Burden of Child Care", mimeo, University of North Carolina at Greensboro, May.

Rothschild, Michael, and Joseph Stiglitz. 1976. "Equilibrium in Competitive Insurance Markets: An Essay on the Economics of Imperfect Information" Quarterly Journal of Economics, 90(4), November, 629-49.

Ruhm, Christopher J. 1997. "Policy Watch: The Family and Medical Leave Act", Journal of Economic Perspectives, 11(3), Summer, 175-186.

Ruhm, Christopher J. 1998. "The Economic Consequences of Parental Leave Mandates: Lessons From Europe", Quarterly Journal of Economics, 113(1), February, 285-317.

Ruhm, Christopher J. 2000. "Parental Leave and Child Health" Journal of Health Economics, 19(6), November, 931-960. 
Ruhm, Christopher J. 2003. "Parental Employment and Adolescent Development”, mimeo, University of North Carolina at Greensboro, November.

Ruhm, Christopher J. 2004. "Parental Employment and Child Cognitive Development", Journal of Human Resources, 39(1), Winter.

Sandberg, John F. and Sandra L. Hofferth. 2001. "Changes in Children's Time With Parents: United States, 1981-1997”, Demography, 38(3), August, 423-436.

Shore, Rima. 1997. Rethinking the Brain: New Insights Into Early Development. New York: Families and Work Institute.

Shonkoff, Jack P. and Deborah A. Phillips (eds.). 2000. From Neurons to Neighborhoods: The Science of Early Childhood Development. Washington D.C.: National Academy Press.

Social Security Administration, Office of Research, Evaluation and Statistics. 2002. Social Security Programs Throughout the World: Europe, 2002, Washington D.C.: U.S. Government Printing Office. Accessed on June 11, 2003 from: http://www.ssa.gov/policy/docs/progdesc/ssptw/2002/europe/ssptw02euro.pdf.

U.S. Bureau of the Census. 2001. Vital Statistics of the United States 1999, Vol. 1, Natality. Washington, D.C.: U.S. Government Printing Office, accessed from: http://www.cdc.gov/nchs/data/statab/t991x07.pdf on June 11, 2003.

U.S. Bureau of the Census. 2002. Statistical Abstract of the United States: 2002 (122 ${ }^{\text {nd }}$ Edition). Washington D.C.: U.S. Government Printing Office.

U.S. Bureau of the Census. 2003. Living Arrangements of Children Under 18 Years Old: 1960 to Present, internet release date June 12, accessed from url: http://www.census.gov/population/socdemo/hh-fam/tabCH-1.pdf on June 12, 2003.

U.S. Bureau of the Census. Various Years. Statistical Abstract of the United States: 1981-1988, $1990,1991,1993,1995,1998,1999$ (101-108, 110, 111, 113, 115, 118, $119^{\text {th }}$ Editions).

Washington D.C.: U.S. Government Printing Office.

U.S. Department of Labor, Employment Standards Administration. 2003. Fact Sheet No. 28: The Family and Medical Leave Act of 1993, accessed on June 10, 2003 from: http://www.dol.gov/esa/regs/compliance/whd/whdfs28.htm.

U.S. Department of Labor, Bureau of Labor Statistics. 1988. Labor Force Statistics Derived from the Current Population Survey, 1948-87, Bulletin 2307, Tables C12-C14.

U.S. Department of Labor, Bureau of Labor Statistics. 1999. Employee Benefits in Medium and Large Private Establishments, 1997, Bulletin 2517, Table 3. Accessed on June 6, 2003 from http://www.bls.gov/ncs/ebs/sp/ebbl0017.pdf.

U.S. Department of Labor, Bureau of Labor Statistics. 2001. National Compensation Survey: Employee Benefits in Private Industry in the United States, 1999 Supplementary Tables. Accessed on June 5, 2003 from: <http://www.bls.gov/ncs/ebs/sp/ebtb0001.pdf>. 
U.S. Department of Labor, Bureau of Labor Statistics. 2003. Employee Benefits in Private Industry in the United States, Supplementary Tables, Bulletin 2555, Table 1. Accessed on June 5, 2003 from http://www.bls.gov/ncs/ebs/sp/ebtb0002.pdf.

Waldfogel, Jane. 2001. "Family and Medical Leave Act: Evidence from the 2000 Surveys", Monthly Labor Review, 124(9), September, 17-23.

Zick, Cathleen D. and W. Keith Bryant. 1996. “A New Look at Parents' Time Spent in Child Care: Primary and Secondary Time Use" Social Science Research, 25(3), 260-280. 
Table 1: Employee Benefits in Medium and Large Private Establishments

\begin{tabular}{|c|c|c|c|c|c|c|c|c|c|c|c|c|c|c|c|}
\hline & 1980 & 1981 & 1982 & 1983 & 1984 & 1985 & 1986 & 1988 & 1989 & 1991 & 1993 & 1995 & 1997 & 1999 & 2000 \\
\hline \multicolumn{16}{|l|}{ Paid: } \\
\hline Holidays & 99 & 99 & 99 & 99 & 99 & 98 & 99 & 96 & 97 & 92 & 91 & 89 & 89 & 90 & 92 \\
\hline Vacations & 100 & 99 & 99 & 100 & 99 & 99 & 100 & 98 & 97 & 96 & 97 & 96 & 95 & 93 & 95 \\
\hline Sick leave & 62 & 65 & 67 & 67 & 67 & 67 & 70 & 69 & 68 & 67 & 65 & 58 & 56 & 67 & - \\
\hline Personal leave & 20 & 23 & 24 & 25 & 23 & 26 & 25 & 24 & 22 & 21 & 21 & 22 & 20 & - & - \\
\hline Maternity leave & - & - & - & - & - & - & - & 2 & 3 & 2 & 3 & - & - & - & - \\
\hline Paternity leave & - & - & - & - & - & - & - & 1 & 1 & 1 & 1 & - & - & - & - \\
\hline Family leave & - & - & - & - & - & - & - & - & - & - & - & 2 & 2 & - & - \\
\hline \multicolumn{16}{|l|}{ Unpaid: } \\
\hline Maternity leave & - & - & - & - & - & - & - & 33 & 37 & 37 & 60 & - & - & - & - \\
\hline Paternity leave & - & - & - & - & - & - & - & 16 & 18 & 26 & 53 & - & - & - & - \\
\hline Family leave & - & - & - & - & - & - & - & - & - & - & - & 84 & 93 & - & - \\
\hline \multicolumn{16}{|l|}{ Child Care: } \\
\hline $\begin{array}{l}\text { Any employer } \\
\text { assistance }\end{array}$ & - & - & - & - & - & - & - & 4 & 5 & 8 & 7 & 8 & 10 & 9 & 9 \\
\hline Provided funds & - & - & - & - & - & - & - & - & - & - & - & 4 & 6 & 5 & 4 \\
\hline On-site child care & - & - & - & - & - & - & - & - & - & - & - & 3 & 3 & 4 & 4 \\
\hline Off-site child care & - & - & - & - & - & - & - & - & - & - & - & 1 & 1 & 3 & 2 \\
\hline
\end{tabular}

Note: Table shows the percentage of full-time employees participating in or eligible for the specified benefit. From 1980 until 1986 , medium and large establishments exclude firms with less than 50 to 250 employees, depending on the industry. After 1986, the medium and large firms are defined as having 100 or more employees. After the 1993 survey, maternity and paternity leave are combined and reported as family leave. Personal Leave is not reported after 1997.

Sources: U.S. Census Bureau; Statistical Abstract of the United States, various years (1981-1988, 1990, 1991, 1993, 1995, 1998, 1999); U.S. Department of Labor, Bureau of Labor Statistics (1999, 2003). 
Table 2: Employee Benefits in Small Private Establishments

\begin{tabular}{lcccccc}
\hline & $\mathbf{1 9 9 0}$ & $\mathbf{1 9 9 2}$ & $\mathbf{1 9 9 4}$ & $\mathbf{1 9 9 6}$ & $\mathbf{1 9 9 9}$ & $\mathbf{2 0 0 0}$ \\
\hline Paid Holidays & 84 & 82 & 82 & 80 & 84 & 83 \\
Paid Vacations & 88 & 88 & 88 & 86 & 87 & 87 \\
Paid Sick leave & 47 & 53 & 50 & 50 & 59 & - \\
Paid Personal leave & 11 & 12 & 13 & 14 & - & - \\
Paid Maternity leave & 2 & 2 & - & - & - & - \\
Paid Paternity leave & $<.5$ & 1 & - & - & - & - \\
Paid Family leave & - & - & 2 & 2 & - & - \\
& & & & & & \\
Unpaid Maternity leave & 17 & 18 & - & - & - & - \\
Unpaid Paternity leave & 8 & 8 & - & - & - & - \\
Unpaid Family leave & - & - & 47 & 48 & - & - \\
& & & & & & \\
Child Care: & & & & & & \\
Any employer assistance & 1 & 2 & 1 & 2 & 2 & 1 \\
Provided funds & - & - & 1 & 1 & 2 & $<.5$ \\
On-site child care & - & - & 1 & 1 & 1 & $<.5$ \\
Off-site child care & - & - & $<.5$ & 1 & $<.5$ & 1 \\
\hline
\end{tabular}

Note: See note on table 1. Small establishments include those with fewer than 100 employees. Results are for full time employees.

Sources: U.S. Census Bureau; Statistical Abstract of the United States, various years (1992, 1994, 1997, 1998); U.S. Department of Labor, Bureau of Labor Statistics (2001, 2003) 


\section{Table 3: Key Features of Family and Medical Leave Act (FMLA)}

\section{Effective Date}

Benefit

Uses

Coverage

Eligibility

Job Security
August 5, 1993

12 weeks of unpaid leave in 12 month period. Health insurance continued and employee may be required to use accrued sick leave/vacation.

Care of newborn/adopted children, relatives with serious medical conditions, own health problems.

Private establishments employing 50 or more persons within 75 miles of worksite during at least 20 weeks of current/previous year. All public agencies covered.

Worked for covered employer for at least 1,250 hours in previous 12 months.

Reinstatement into original or equivalent job guaranteed, except for "key" employees (salaried and among the highest paid 10 percent of employees within 75 miles of work site).

Source: U.S. Department of Labor, Employment Standards Administration (2003). 
Table 4: Paid Parental Leave in 2002

\begin{tabular}{|c|c|c|c|c|}
\hline Country & $\begin{array}{c}\text { Leave } \\
\text { Entitlement }\end{array}$ & Rate of Pay & $\begin{array}{l}\text { Source of } \\
\text { Funds }\end{array}$ & Qualification Conditions \\
\hline Austria & 16 weeks & $\begin{array}{l}100 \% \\
\text { with maximum }\end{array}$ & $\begin{array}{l}\text { Payroll Taxes, } \\
\text { Government }\end{array}$ & In covered employment. \\
\hline Belgium & 15 weeks & $\begin{array}{l}82 \% \text { in first month, } \\
75 \% \text { thereafter } \\
\text { with maximum }\end{array}$ & $\begin{array}{c}\text { Payroll Taxes, } \\
\text { Government }\end{array}$ & $\begin{array}{l}\text { Insured } 6 \text { months before } \\
\text { leave. }\end{array}$ \\
\hline Denmark & 30 weeks & $\begin{array}{c}100 \% \\
\text { with maximum }\end{array}$ & $\begin{array}{l}\text { Employers, } \\
\text { Government }\end{array}$ & $\begin{array}{l}74 \text { hours of employment in } \\
\text { preceding } 8 \text { weeks. }\end{array}$ \\
\hline Finland & 53 weeks & $\begin{array}{l}70 \% \text { with } \\
\text { minimum; lower rate } \\
\text { at high incomes }\end{array}$ & $\begin{array}{l}\text { Payroll Taxes, } \\
\text { Government }\end{array}$ & Residence in Country. \\
\hline France & 16 weeks & $\begin{array}{c}100 \% \\
\text { with maximum }\end{array}$ & $\begin{array}{c}\text { Payroll and } \\
\text { Dedicated Taxes }\end{array}$ & $\begin{array}{l}200 \text { hours of paid } \\
\text { employment in } 3 \text { months } \\
\text { before pregnancy. }\end{array}$ \\
\hline Germany & 14 weeks & $\begin{array}{l}100 \% \\
\text { with minimum and } \\
\text { maximum }\end{array}$ & $\begin{array}{l}\text { Payroll Taxes, } \\
\text { Government }\end{array}$ & Residence in Country. \\
\hline Greece & 17 weeks & $\begin{array}{l}50 \% \\
\text { with minimum }+10 \% \\
\text { for each dependent }\end{array}$ & $\begin{array}{c}\text { Payroll Taxes, } \\
\text { Government }\end{array}$ & $\begin{array}{l}200 \text { days of contributions } \\
\text { during last } 2 \text { years. }\end{array}$ \\
\hline Ireland & 18 weeks & $\begin{array}{c}70 \% \\
\text { with maximum }\end{array}$ & $\begin{array}{l}\text { Payroll Taxes, } \\
\text { Government }\end{array}$ & $\begin{array}{l}39 \text { weeks of contributions in } \\
\text { previous year or } 52 \text { weeks in } \\
\text { prior } 2 \text { years. }\end{array}$ \\
\hline Italy & 48 weeks & $\begin{array}{l}80 \% \text { first } 5 \text { months } \\
30 \% \text { next } 6 \text { months }\end{array}$ & $\begin{array}{l}\text { Employers, } \\
\text { Government }\end{array}$ & $\begin{array}{l}\text { Employed and insured at } \\
\text { start of pregnancy. }\end{array}$ \\
\hline Netherlands & 12 weeks & $\begin{array}{c}100 \% \\
\text { with maximum }\end{array}$ & $\begin{array}{c}\text { Payroll Taxes, } \\
\text { Government }\end{array}$ & Employed or unemployed. \\
\hline Norway & 42 weeks & $\begin{array}{l}100 \% \\
\text { with maximum }\end{array}$ & $\begin{array}{l}\text { Payroll Taxes, } \\
\text { Government }\end{array}$ & $\begin{array}{l}\text { Employed in } 6 \text { of last } 10 \\
\text { months. }\end{array}$ \\
\hline Portugal & 30 weeks & $\begin{array}{l}100 \% \\
\text { with minimum }\end{array}$ & $\begin{array}{l}\text { Payroll Taxes, } \\
\text { Government }\end{array}$ & $\begin{array}{l}\text { Employed with } 6 \text { months of } \\
\text { insurance contributions. }\end{array}$ \\
\hline Sweden & 76 weeks & $\begin{array}{c}80 \%, 63 \text { weeks } \\
\text { flat rate, } 13 \text { weeks }\end{array}$ & Payroll Taxes & $\begin{array}{l}\text { Insured } 240 \text { days before } \\
\text { childbirth. }\end{array}$ \\
\hline Switzerland & 16 weeks & $\begin{array}{l}\text { varies with type of } \\
\text { insurance fund }\end{array}$ & $\begin{array}{l}\text { Social Insurance } \\
\text { Premiums }\end{array}$ & $\begin{array}{l}9 \text { months of insurance } \\
\text { contributions. }\end{array}$ \\
\hline $\begin{array}{l}\text { United } \\
\text { Kingdom }\end{array}$ & 18 weeks & $\begin{array}{c}90 \% \\
\text { with maximum }\end{array}$ & $\begin{array}{l}\text { Payroll Taxes, } \\
\text { Employers, } \\
\text { Government }\end{array}$ & $\begin{array}{l}6 \text { months employment in } \\
\text { previous } 15 \text { months, with } \\
\text { minimum earnings. }\end{array}$ \\
\hline
\end{tabular}

Sources: Ruhm (2000); Social Security Administration, Office of Research, Evaluation and Statistics (2002). 
Table 5: Child Care Cost Burden and Its Components

\begin{tabular}{lccccc}
\hline Cost Burden Component & $\begin{array}{c}\text { Sample } \\
\text { Mean }\end{array}$ & $\mathbf{0 - 6 3}$ & $\mathbf{6 3 - 7 5}$ & $\mathbf{7 5 - 9 0}$ & $\mathbf{9 0 - 1 0 0}$ \\
\hline Child Care Cost Burden & $4.9 \%$ & $0 \%$ & $3.1 \%$ & $10.1 \%$ & $29.7 \%$ \\
& $(0.1 \%)$ & $(0 \%)$ & $(0.1 \%)$ & $(0.1 \%)$ & $(0.5 \%)$ \\
Monthly Child Care Costs & $\$ 135$ & $\$ 0$ & $\$ 145$ & $\$ 365$ & $\$ 624$ \\
& $(\$ 4)$ & $(\$ 0)$ & $(\$ 6)$ & $(\$ 7)$ & $(\$ 20)$ \\
Weekly Child Care Hours & 25.0 & 12.5 & 29.1 & 47.5 & 65.1 \\
& $(0.5)$ & $(0.5)$ & $(1.1)$ & $(1.0)$ & $(1.8)$ \\
Monthly Family Income & $\$ 3,060$ & $\$ 2,708$ & $\$ 4,757$ & $\$ 3,706$ & $\$ 2,268$ \\
& $(\$ 39)$ & $(\$ 47)$ & $(\$ 156)$ & $(\$ 65)$ & $(\$ 84)$ \\
\hline
\end{tabular}

Note: The child care cost burden is defined as the cost of non-immediate family day care for children aged 5 and under divided by total family income after subtracting taxes and adding transfer payments. Standard errors are in parentheses.

Source: Rosenbaum and Ruhm (2003). 
Table 6: Sources and Costs of Care for Pre-School Aged Children

\begin{tabular}{lccccc}
\hline Mode of Child Care & $\begin{array}{c}\text { Hours } \\
\text { Per Week }\end{array}$ & $\begin{array}{c}\text { Percent } \\
\text { Using }\end{array}$ & $\begin{array}{c}\text { Dollars } \\
\text { Per Hour }\end{array}$ & $\begin{array}{c}\text { Dollars } \\
\text { Per } \\
\text { Month }\end{array}$ & $\begin{array}{c}\text { Percent } \\
\text { Receiving } \\
\text { Free } \\
\text { Care }\end{array}$ \\
\hline All Non-Immediate Family Care & 25.0 & $60.2 \%$ & $\$ 1.24$ & $\$ 135$ & $39.0 \%$ \\
Relative/Grandparent & 10.0 & $29.8 \%$ & $\$ 0.31$ & $\$ 13$ & $76.3 \%$ \\
Non-Relative & 3.4 & $11.4 \%$ & $\$ 1.77$ & $\$ 26$ & $18.0 \%$ \\
Family Day Care & 3.4 & $8.4 \%$ & $\$ 1.77$ & $\$ 26$ & $10.1 \%$ \\
Center/Pre-School & 7.9 & $22.7 \%$ & $\$ 2.01$ & $\$ 69$ & $12.4 \%$ \\
Head Start & 0.3 & $1.2 \%$ & $\$ 0.13$ & $\$ 0$ & $82.3 \%$ \\
\hline
\end{tabular}

Note: This table excludes child care provided by parents and siblings.

Source: Rosenbaum and Ruhm (2003). 
Figure 1: Labor Force Participation Rates of Mothers by Age of Children

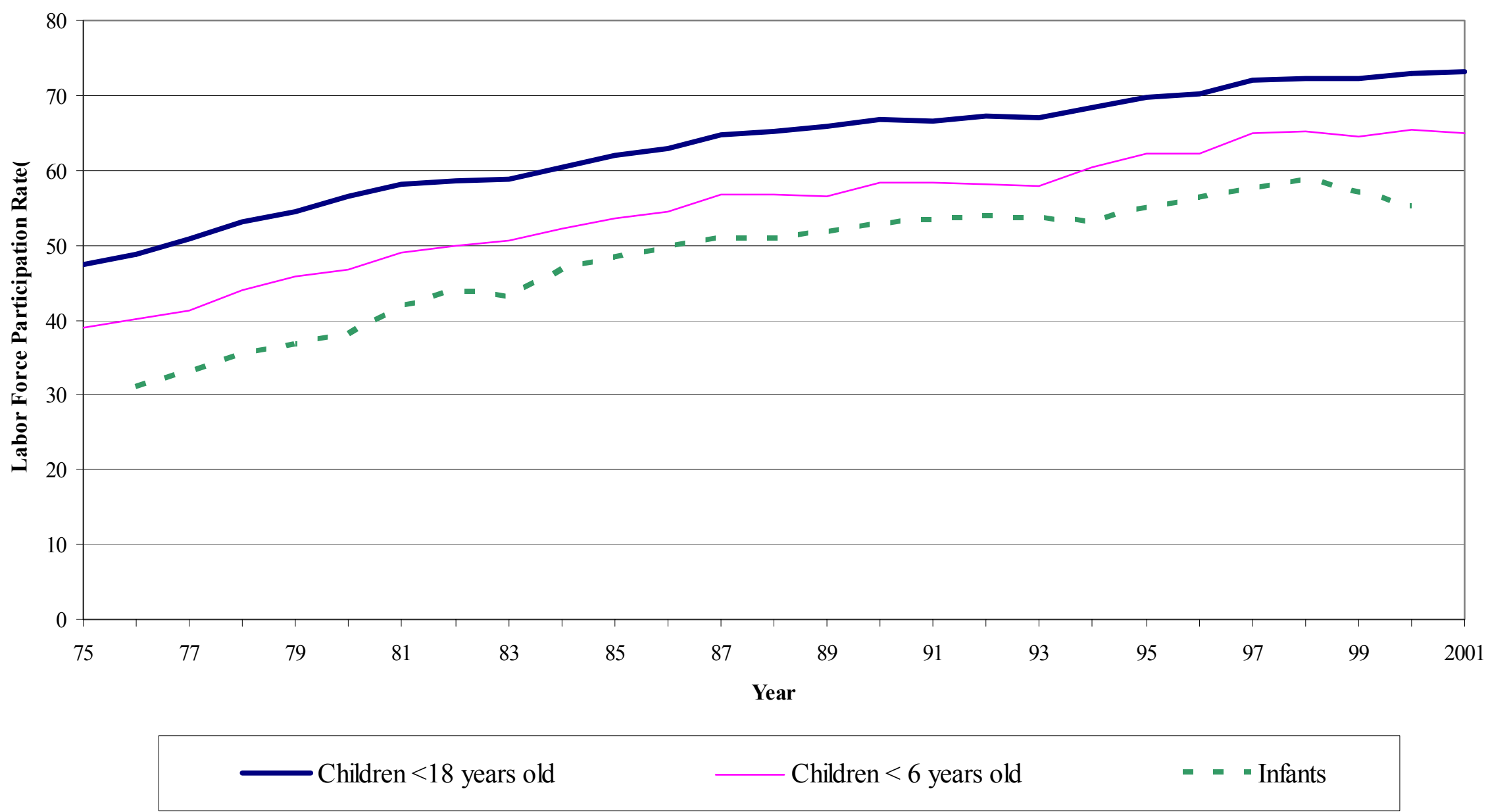

Sources: U.S. Department of Labor, Bureau of Labor Statistics (1988); U.S. Bureau of the Census, Statistical Abstract of the United States various years (1987-2002); Bachu and O'Connell (2001). Data for mothers with infants are interpolated for 1977, 1979, 1989, 1991, 1993, 1996, 1997, and 1999. 


\section{Figure 2: Labor Force Participation Rates of Mothers with Children Under the Age of Six}

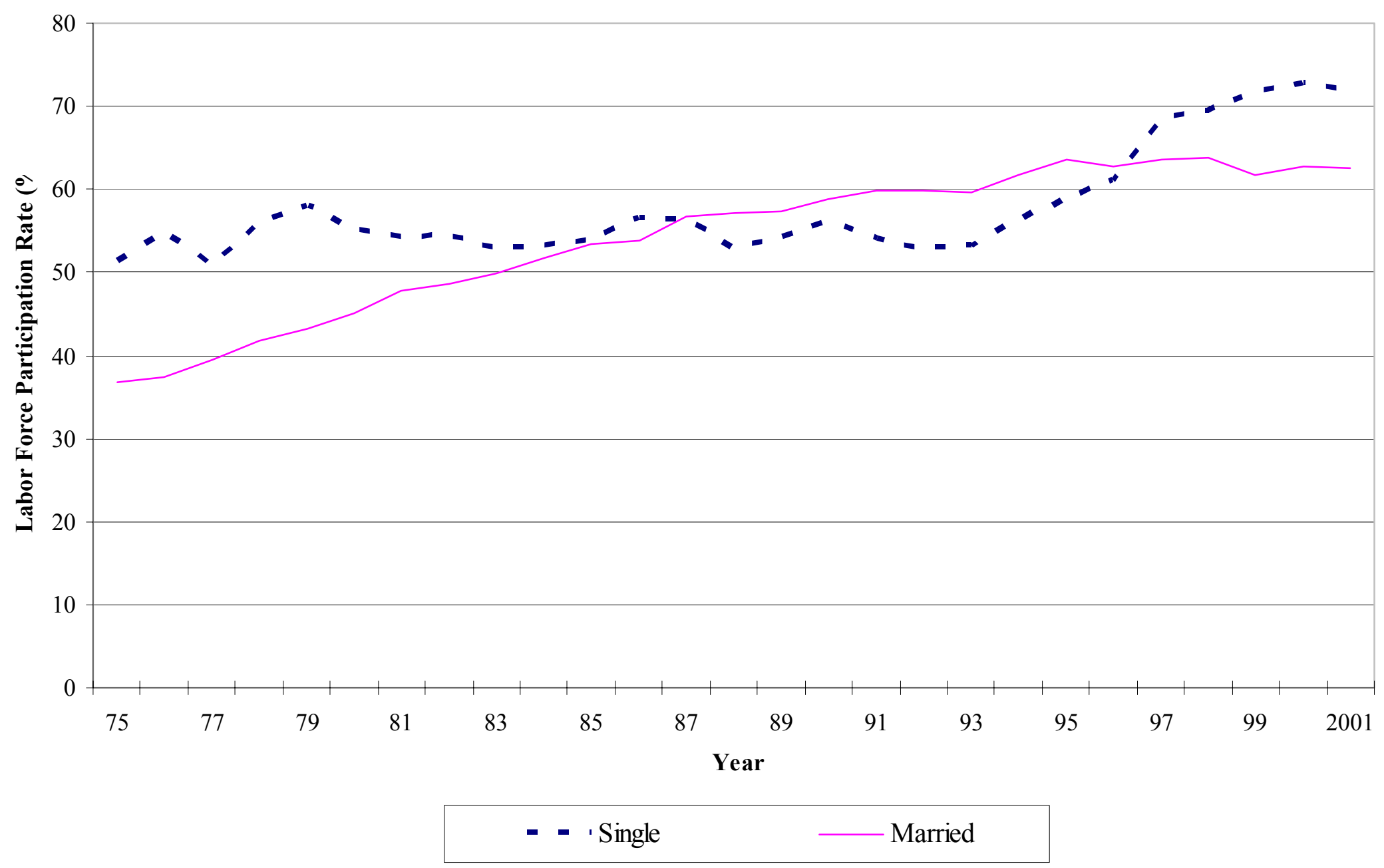

Sources: U.S. Department of Labor, Bureau of Labor Statistics (1988); U.S. Bureau of the Census, Statistical Abstract of the United States various years (1987-2002). Single mothers are defined as those who have never been married or are divorced, separated, or widowed. 
Figure 3: Employment Probabilities and Hazard Rates of Mothers in Weeks After Birth

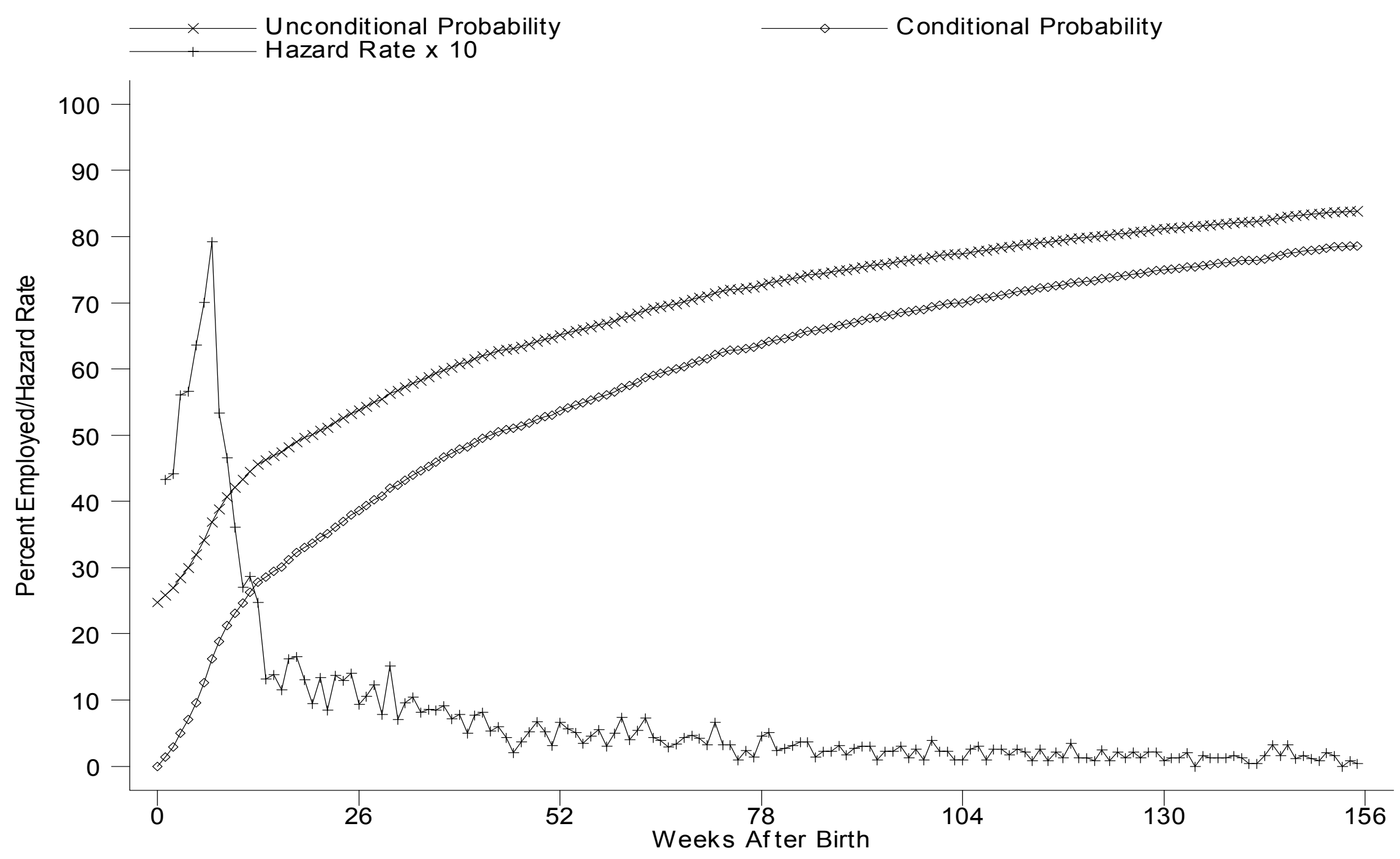

Source: Ruhm (2004). 